\title{
Exercise, appetite and weight management: understanding the compensatory responses in eating behaviour and how they contribute to variability in exercise-induced weight loss
}

\author{
N A King, ${ }^{1}$ K Horner, ${ }^{1}$ A P Hills, ${ }^{1}$ N M Byrne, ${ }^{1}$ R E Wood, ${ }^{1}$ E Bryant, ${ }^{2}$ P Caudwell, ${ }^{3}$ \\ G Finlayson, ${ }^{3}$ C Gibbons, ${ }^{3}$ M Hopkins, ${ }^{4}$ C Martins, ${ }^{5}$ J E Blundell ${ }^{3}$
}

${ }^{1}$ Institute of Health and Biomedical Innovation, Queensland University of Technology, Brisbane, Australia

${ }^{2}$ Centre for Psychology Studies, University of Bradford, Bradford, UK ${ }^{3}$ BioPsychology Group Institute of Psychological Sciences, University of Leeds, Leeds, UK

${ }^{4}$ Department of Sport, Health, Leisure and Nutrition, Leeds Trinity University College, Leeds, UK

${ }^{5}$ Obesity Research Group, Department of Cancer Research and Molecular Medicine, Norwegian University of Science and Technology, Trondheim, Norway

\section{Correspondence to}

N A King, Institute of Health and Biomedical Innovation, Queensland University of Technology, Brisbane 4059, Australia;

n.king@qut.edu.au

Accepted 13 April 2011

\begin{abstract}
Does exercise promote weight loss? One of the key problems with studies assessing the efficacy of exercise as a method of weight management and obesityis that mean data are presented and the individual variability in response is overlooked. Recent data have highlighted the need to demonstrate and characterise the individual variability in response to exercise. Do people who exercise compensate for the increase in energy expenditure via compensatory increases in hunger and food intake? The authors address the physiological, psychological and behavioural factors potentially involved in the relationship between exercise and appetite, and identify the research questions that remain unanswered. A negative consequence of the phenomena of individual variability and compensatory responses has been the focus on those who lose little weight in response to exercise; this has been used unreasonably as evidence to suggest that exercise is a futile method of controlling weight and managing obesity. Most of the evidence suggests that exercise is useful for improving body composition and health. For example, when exercise-induced mean weight loss is $<1.0 \mathrm{~kg}$, significant improvements in aerobic capacity $(+6.3 \mathrm{ml} / \mathrm{kg} / \mathrm{min})$, systolic $(-6.00$ $\mathrm{mm} \mathrm{Hg})$ and diastolic $(-3.9 \mathrm{~mm} \mathrm{Hg})$ blood pressure, waist circumference $(-3.7 \mathrm{~cm})$ and positive mood still occur. However, people will vary in their responses to exercise; understanding and characterising this variability will help tailor weight loss strategies to suit individuals.
\end{abstract}

\section{INTRODUCTION}

Exercise is frequently used as a method of weight control through an increase in energy expenditure (EE), with the aim of creating a sustained energy deficit. Of course, compliance to the exercise itself is an important issue; however, of more interest is the issue of compensatory responses, which undermines the ability of exercise to promote theoretical weight loss. ${ }^{1}$

There have been a multitude of studies examining the acute effects of exercise on compensatory responses in energy intake (EI). The acute effects of exercise appear to be consistent and relatively well understood. The majority of research demonstrates that acute exercise does not increase hunger, the desire to eat or EI. ${ }^{2-6}$ Even when there is a marked increment of $4.6 \mathrm{MJ} /$ day in acute exercise-induced $\mathrm{EE}$, and $\mathrm{EI}$ is monitored for 2 days, there is no automatic increase in EI. ${ }^{7}$
Although the acute effects of exercise on EI are generally consistent, there are a few rare examples of a coupling between EE and EI. ${ }^{8} 9$ More recently, partial compensation to an exercise-induced energy deficit has been reported. ${ }^{10-12}$ It has also been demonstrated that exercise improves the sensitivity of appetite control and regular exercisers are better at detecting the difference in energy content between low- and high-energy preloads compared with their sedentary counterparts. ${ }^{13} 14$

Overall, the evidence suggests that no or only partial compensation occurs in response to an acute exercise-induced energy deficit. Therefore, exercise should provide a successful method of weight control. The effects of chronic exercise on EI and appetite are less clear. Long-term studies that have monitored EI for between 16 weeks and 18 months in overweight men and women also demonstrated no significant change in EI across the intervention. ${ }^{15-17}$ Weight loss is typically low and variable in most of these long-term studies. It is important to note that there is a tendency for the exercise sessions to be unsupervised, the absolute increase in EE is low and the methods used to measure food intake are not reliable. Therefore, it is possible that the increase in exercise-induced $\mathrm{EE}$ is insufficient to upregulate EI to a detectable level. Even when the exercise was supervised and induced an energy deficit of approximately 8.2 MJ/week for 16 months, there was no increase in EI. ${ }^{18}$ These data suggest that there tends to be a lack of an increase in EI to compensate for an exercise-induced energy deficit in overweight and obese individuals. However, increases in EI in response to long-term exercise have been reported in lean participants. ${ }^{19-21}$ Therefore, one hypothesis is that lean individuals demonstrate a compensatory increase in EI to defend their relatively lower body fat reserves. It is important to recognise that for a majority of published research, mean data are reported, which may disguise other trends in the data, for example, individual variability. A series of systematic studies has recently provided data to identify and characterise individuals who experience different changes in body weight after 12 weeks of supervised exercise. ${ }^{22-24}$ These data have revived interest in characterising and explaining the variability by focusing on compensatory responses. 


\section{INDIVIDUAL VARIABILITY: DO ALL PEOPLE RESPOND SIMILARLY?}

Although there is some substance in the claim that some or all of the weight loss is regained or weight loss eventually reaches a plateau (eg, refs $25^{-2}$ ), the overriding assumption is that people should experience similar weight loss in response to exercise. Evidence indicates that even when the exercise is supervised and closely monitored, there is variability in weight change, both in the direction and magnitude. ${ }^{24}$ Figure 1 shows individual changes in body weight after a 12 -week supervised exercise intervention in overweight males and females. The intervention consisted of five high-intensity $\left(70 \% \mathrm{VO}_{2 \max }\right)$ exercise sessions per week. The intensity and duration was fixed for all individuals and the EE of each exercise session was $~ 2 \mathrm{MJ}$. These demonstrate that despite the same imposed increase in EE, individuals will vary in their body weight response.

The phenomenon of individual variability in response to energy balance perturbations is certainly not new. ${ }^{29-31}$ However, exercise-induced individual variability has yet to be exploited, in particular, the characterisation of the variability, and the behavioural and physiological compensatory processes need to be determined. More recently, individual variability has attracted new interest. ${ }^{1} 222432-36$ Unfortunately, reports of the variabilityinexercise-inducedweightchangeresultsinthemedia using the evidence unreasonably (http:/www.telegraph.co.uk/ science/6083234/Health-warning-exercise-makes-you-fat. html; http://www.time.com/time/health/article/0,8599, $1914857,00 . \mathrm{html})^{37} 38$ to argue that exercise is a futile method of weight loss, by unjustly focusing on those who experience no or little weight loss. We acknowledge that some individuals do experience minimal exercise-induced weight loss and that these individuals need further examination. However, exercise should be portrayed more positively. Overall, the evidence demonstrates that exercise does lead to improvements in body composition and fat mass loss, ${ }^{39}$ and, more importantly, the beneficial health effects of exercise are not restricted by the absence of or a low weight loss. Based on changes in body weight after 12 weeks of supervised exercise, two groups were

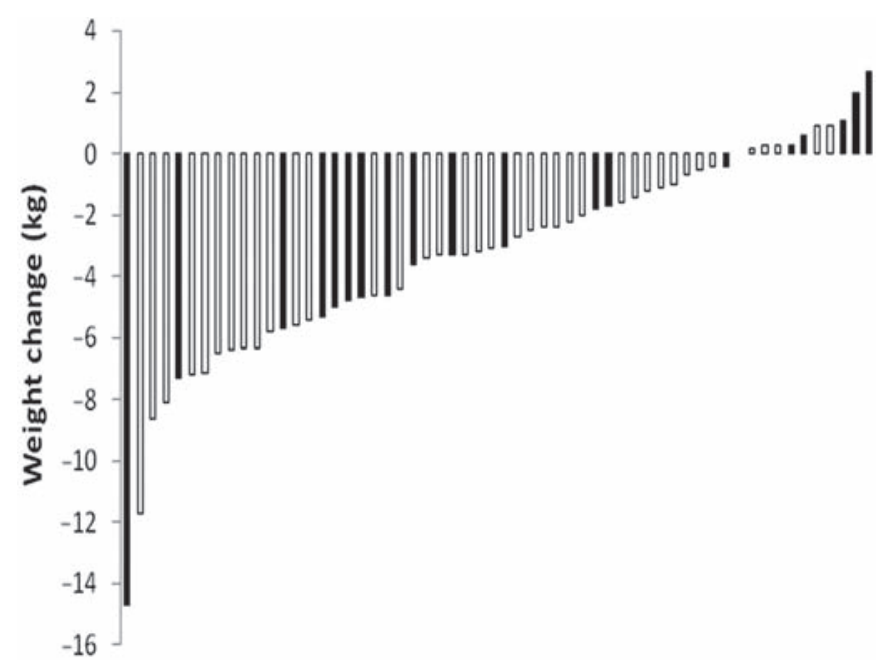

Figure 1 Individual variability in changes in body weight in overweight and obese men and women $(n=58)$ after 12 weeks of supervised exercise. Each histogram represents an individual's change in weight. There was no difference between men (filled bars) and women (open bars). Data from King et al. ${ }^{24}$ identified: responders and non-responders. Despite the nonresponders losing significantly less weight than the responders $(0.9 \mathrm{~kg}$ vs $5.2 \mathrm{~kg})$, they still experienced marked improvements in blood pressure, waist circumference and $\mathrm{VO}_{2 \max }$ (see table 1). Rather than using individual variability as an opportunity to deter those who experience poor weight loss from exercising, there is a need to understand what accounts for the variability and how that information can be used to develop weight management strategies to facilitate weight loss (and maintenance) in those people. Furthermore, there is a need to educate people that improvements in health occur even in the absence of lower-than-expected weight loss. The concept of susceptibility to weight gain, and resistance to weight loss, has been discussed in detail elsewhere. ${ }^{40} 41$ There is an urgent need to determine why some people lose less weight than is theoretically expected in response to energy balance interventions, particularly, exercise interventions.

\section{EXERCISE-INDUCED PHYSIOLOGICAL PROCESSES OF APPETITE CONTROL}

\section{Gastric emptying and gut physiology}

Given the central role that the gut and its related hormonal activity play in appetite control, it is possible that they also moderate the responses to acute or chronic exercise. Gastric distension, in combination with the presence of nutrients in the small intestine, contributes to satiety. ${ }^{42} 43$ Gastric emptying inevitably affects food intake and appetite control through the delivery of nutrients to the small intestine. ${ }^{44}$ The classical studies reported an inverse relationship between the rate of gastric emptying and satiety. ${ }^{45-47}$ More recently, the importance of considering the biphasic role of gastric emptying in satiation (meal size) and satiety (intermeal interval) has been highlighted, with the suggestion that a decrease in the initial emptying rate could result in a delay in the release of potent signals involved in meal termination. ${ }^{48}$ As satiation and satiety are important processes in appetite regulation, interindividual differences in gut physiology and the strength of these signals could contribute to variability in exercise-induced weight loss.

Surprisingly, very few studies have directly examined the effects of exercise on gastric emptying and appetite. A majority of studies conducted on exercise and gastric emptying have focused on the efficacy of providing optimal rates of carbohydrate and fluid replenishment as ergogenic aids in sport. Overall, the evidence points to a delay in gastric emptying with strenuous exercise $\left(>70 \% \mathrm{VO}_{2 \max }\right),{ }^{49-57}$ whereas mild to moderate exercise stimulates (ie, accelerates) gastric emptying. ${ }^{54}$ 55 58-60 There have also been reports of no change in gastric emptying with moderate intensity exercise. ${ }^{52} 61$ Differences in study methodology such as test meal properties and exercise parameters may account for this inconsistency.

The proposed mechanisms that could contribute to exercise-induced alterations in gastric emptying include changes in contraction frequencies, antral area ${ }^{62}$ and gastric myoelectrical activity, ${ }^{6364}$ hormonal $^{565965}$ and neural factors (mainly vagal in origin), ${ }^{58} 66$ gut blood flow ${ }^{54}$ and the mechanical effects of 'jostling of the gut'54 565967 during exercise.

In terms of adaptation to regular exercise, very few studies have examined the impact of chronic exercise exclusively on gastric emptying at rest or during exercise. Despite not controlling for age, Shimamoto et al ${ }^{68}$ reported that at rest, gastric emptying was slower in inactive compared with active old individuals, which was associated with decreased gastric 
Table 1 Changes in body mass, fat mass, waist circumference, blood pressure and $\mathrm{VO}_{2 \max }$ in responders and non-responders after 12 weeks of supervised exercise

\begin{tabular}{llll}
\hline Variable & Group & Absolute change & \% Change \\
\hline Body mass $(\mathrm{kg})$ & Responders & -5.2 & -5.7 \\
& Non-responders & -0.9 & -1 \\
Fat mass $(\mathrm{kg})$ & Responders & -4.9 & -15.3 \\
& Non-responders & -1.2 & -4.7 \\
Lean mass $(\mathrm{kg})$ & Responders & -0.3 & -0.6 \\
& Non-responders & 0.3 & 0.4 \\
Waist & Responders & -6 & -5.8 \\
circumference $(\mathrm{cm})$ & Non-responders & -3.7 & -3.7 \\
V0 $_{2 \max }(\mathrm{ml} / \mathrm{kg} / \mathrm{min})$ & Responders & 9.1 & 32.5 \\
& Non-responders & 6.3 & 23 \\
Diastolic blood & Responders & -3.4 & -3.7 \\
pressure $(\mathrm{mm} \mathrm{Hg})$ & Non-responders & -3.9 & -4.6 \\
Systolic blood & Responders & -2.9 & -1.9 \\
pressure $(\mathrm{mm} \mathrm{Hg})$ & Non-responders & -6 & -4.3 \\
\hline
\end{tabular}

Adapted from King et al. ${ }^{39}$

electroactivity in the inactive group. In a cross-sectional study, a faster basal rate of gastric emptying was observed in marathon runners compared with sedentary controls. ${ }^{69}$ Traininginduced enhanced parasympathetic tone was proposed as one possible explanation.

Of course, physical activity (hence EE) might not be the only factor to vary between inactive and active people. Dietary habits, including total EI, frequency of eating and macronutrient intake, could also vary. Collectively, these dietary factors could affect gastric motility, via the quantity, frequency and quality of nutrients that pass through the gut and small intestine. A high-fat/low-carbohydrate diet attenuates the effects of fat on gastric emptying ${ }^{70} 71$ and intestinal transit. ${ }^{72}$ Harris et $a^{73}$ reported rapid orocecal transit time (OCTT) in chronically active individuals with concomitant high EIs, and concluded that the high EI associated with chronic exercise may be associated with significant gastrointestinal adaptations (figure 2). However, the causal nature of this association is not possible to determine from this cross-sectional study. It could also be speculated that increased physical activity levels may have led to faster OCTT and thus higher caloric intakes as a result of a shorter satiety period.

\section{Appetite peptides}

Appetite-related peptides play an important role in the stimulation or inhibition of eating in accordance with the principles of energy balance. For example, ghrelin is an orexigenic peptide secreted from the stomach. ${ }^{74}$ Increased postprandial ghrelin suppression is associated with reduced appetite. ${ }^{75}$ A majority of studies indicate that acute exercise has no influence on total ghrelin (TG) concentrations. ${ }^{76-81}$ One study showed that TG levels are suppressed for an hour after the cessation of exercise, ${ }^{82}$ whereas $3 \mathrm{~h}$ of moderate intensity exercise has been shown to increase TG levels. ${ }^{83}$ The consensus is that acute exercise appears not to influence TG levels independent of mode, intensity or metabolic state in normal weight (NW) and overweight/obese adults. ${ }^{84}$

Unfortunately, few studies have examined the active component of the hormone acylated ghrelin (AG). The first study to investigate AG has shown that running for $60 \mathrm{~min}$ at $~ 75 \%$ $\mathrm{VO}_{2 \max }$ caused a suppression of this orexigenic peptide, with a simultaneous suppression of appetite during and immediately

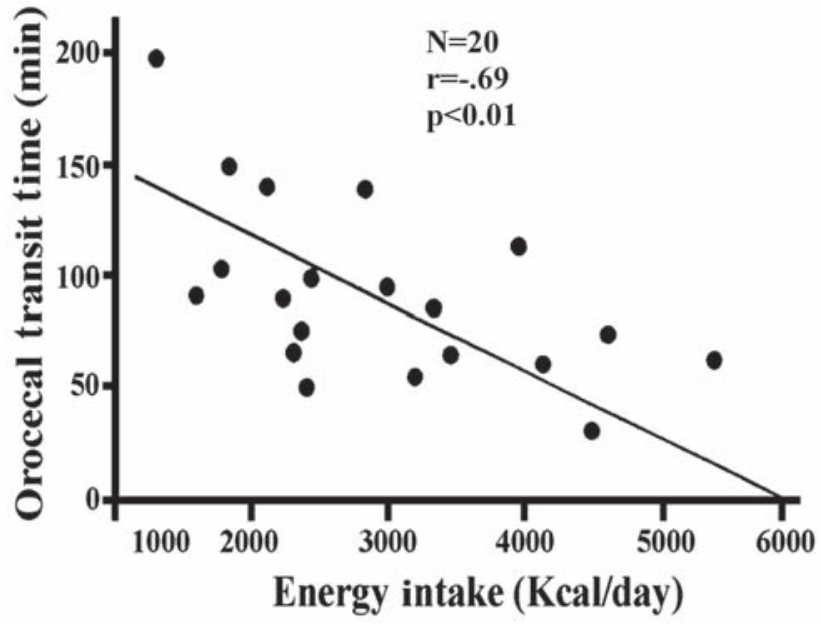

Figure 2 Daily energy and nutrient intakes, and orocecal transit times in 20 physically active men. Data show a negative correlation between mouth to large intestine (orocecal) transit time and daily energy intake. Data from Harris et al. ${ }^{73}$

postexercise in NW trained men. ${ }^{85}$ This evidence suggests that TG and AG respond differently to exercise. Further to this, TG and AG were measured in both NW and obese adults who cycled until exhaustion. ${ }^{86}$ No change in TG was evident, but AG decreased significantly in both groups after exercise even though the obese group reached exhaustion earlier than the NW group. The results of this study emphasise that the mechanism causing the decrease in AG during exercise is independent of adiposity status or acute exercise. ${ }^{86}$

Few studies have investigated the effect of acute exercise on anorexigenic gut peptides. Cholecystokinin (CCK), polypeptide YY (PYY) and glucagon-like peptide-1 (GLP-1) are examples of anorexigenic peptides released in response to intestinal nutrients. ${ }^{74}$ One of the first studies in this area investigated the effects of 60 -min cycling (at $65 \% \mathrm{HR}_{\max }$ ) versus rest (control) on gut peptides and subsequent EI in 12 lean adults after consuming a fixed breakfast. ${ }^{87}$ There was a significant exercise-induced increase in PYY, GLP-1 and pancreatic polypeptide (PP), but no change in TG. The GLP-1 continued to be elevated into the postexercise period, whereas the increase in PYY was short lived. A similar study (cycling at $50 \% \mathrm{VO}_{2 \max }$ for $60 \mathrm{~min}$ ) also reported that both PYY and GLP-1 were significantly increased by exercise, but TG levels remained unaffected. ${ }^{88}$

In acute exercise studies, weight loss is not an issue, whereas in chronic studies in which weight loss occurs, changes in peptides will also be associated with body composition. A significant increase in fasting TG plasma levels has been reported after exercise-induced weight loss in NW, ${ }^{89}$ overweight/obese adults $^{90}$ and in overweight/obese children. ${ }^{91}{ }^{92}$ However, no change in TG plasma levels was reported in overweight twins after 3 months of supervised exercise, inducing a $5 \mathrm{~kg}$ weight loss. ${ }^{93}$ Regarding AG, no change in fasting plasma levels after long-term exercise was reported in overweight children ${ }^{92}$ and adolescents. ${ }^{94}$ However, a significant increase in fasting and postprandial AG levels was reported in NW and overweight adolescents after 5 days of supervised exercise but no change in TG. ${ }^{95}$ We have also recently shown a significant increase in fasting AG plasma levels, despite no change in TG, in overweight/ obese adults after 12 weeks of supervised exercise, inducing an 
average $3.5 \mathrm{~kg}$ weight loss, together with a significant increase in the postprandial suppression of AG (see figure 3). ${ }^{96}$

Although the increase in TG and/or AG plasma levels observed in some exercise-induced weight loss studies can be seen as a counter-regulatory mechanism of restoring EB, TG has been shown to return to baseline levels with sustained weight loss maintenance, both in children ${ }^{91}$ and adults, ${ }^{97}$ suggesting that TG may be involved in the regulation of acute, but not chronic, changes in $\mathrm{EB}$. It remains to be seen if the same is true for AG, because changes in AG do not necessarily parallel changes in TG.

Evidence regarding the impact of chronic exercise on the release of anorexigenic gut peptides is relatively scarce. Longterm exercise has been shown not to change fasting CCK in active men, ${ }^{98}$ but to induce a slight increase in fasting and postprandial $\mathrm{PP}$, in previously sedentary $\mathrm{NW}$ men, ${ }^{99}$ and a significant increase in fasting PYY plasma levels in overweight adolescents. ${ }^{94}$ In overweight/obese adults, exercise-induced weight loss has no impact on fasting PYY or GLP-1 plasma levels, but leads to a tendency towards an increase in the delayed release of GLP-1 (90-180 min) after a meal. ${ }^{96}$ Moreover, no change in fasting GLP-1, but a significant increase in GLP-1 release, in the first 30 min postprandially was reported in NW and overweight adolescents in response to five consecutive days of exercise. ${ }^{100}$

Similar to gastric emptying, habitual diet can influence appetite-related peptides profiles. A high-fat/low-carbohydrate diet attenuates the secretion and action of gut peptides including CCK, PYY, GLP-1 and ghrelin. ${ }^{101-104}$ The interaction of exercise with habitual diet is important to consider as these effects may undermine any potential beneficial effects of exercise on appetite control and therefore contribute to the variability in compensatory responses.

To the best of our knowledge, no studies have systematically examined the complex interactions of changes in gastric emptying and gut peptides and alterations in subjective and
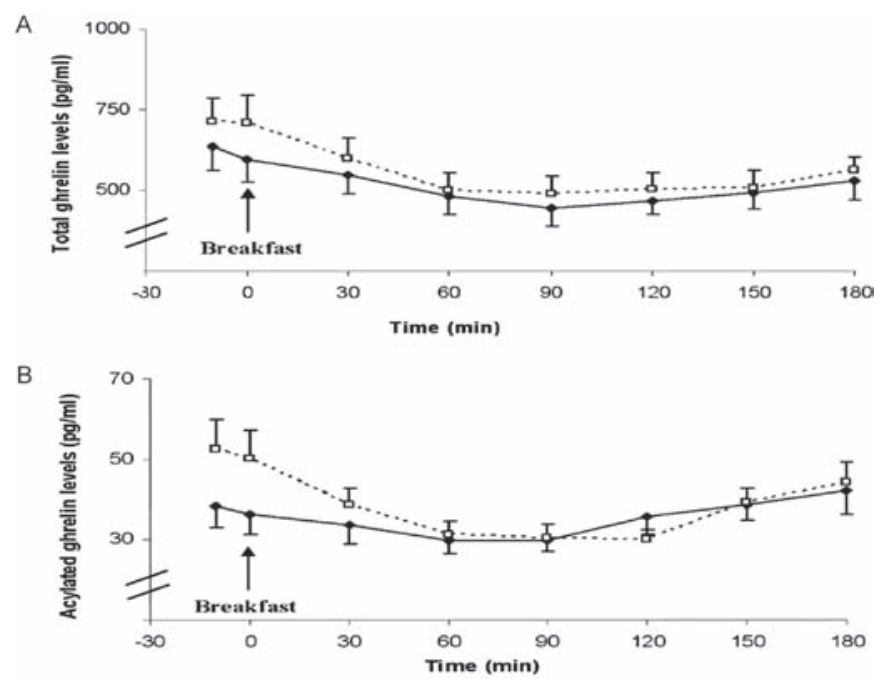

Figure 3 Total ghrelin (A) and acylated ghrelin (B) plasma levels $(\mathrm{pg} / \mathrm{ml})$ during the post-breakfast postprandial period, before (diamonds) and after (squares) a 12-week exercise intervention in overweight/obese individuals $(n=15)$. Despite no change in TG, there was an exercise-induced significant increase in fasting $(p=0.01)$ and postprandial suppression $(p=0.009)$ of $A G$ plasma levels. Values represent means \pm SEM. Adapted from Martins et al. ${ }^{96}$ objective measures of appetite in response to acute or chronic exercise. Therefore, this is an area that needs to be explored because variability in compensatory eating responses could be explained by gut-related activity.

\section{Substrate oxidation}

Consistent with a psychobiological approach to appetite control, in which physiological mediators act as drivers of behaviour, ${ }^{40}$ it is possible that exercise-induced changes in substrate metabolism play an important role in changes in appetite and food intake. Substrate metabolism has long been implicated in the energostatic control of EI, in which fatty acid oxidation (FAO) is thought to mediate EI via the maintenance of postmeal satiety. ${ }^{105}$ Although the mechanisms are poorly understood, changes in hepatic energy status (hepatocellular ATP/ADP ratio) resulting from altered FAO may influence EI via the stimulation of vagal afferent nerve activity. ${ }^{106}$ Aerobic exercise is known to alter substrate utilisation and availability during and following exercise. This may influence the regulation of EI, as it has been suggested that short-term feeding behaviour is designed to maintain the body's glycogen stores at a specific set point, for example, the glycogenostatic theory. ${ }^{107} 108$ Because of its limited capacity for storage, challenges to glycogen availability (via diet or exercise) may act as an internal biological cue that elicits feeding in order to restore glycogen levels. ${ }^{107}$ However, evidence to support a direct link between substrate metabolism during exercise and compensatory eating is limited ${ }^{109}$ and contradictory. ${ }^{110}$ Recent evidence suggests that the maintenance of $\mathrm{CHO}$ balance plays a role in the short-term regulation of EI. Burton et al ${ }^{111}$ reported that a positive $\mathrm{CHO}$ balance at the end of a 6-h 'high-energy turnover' condition (involving exercise and the immediate restoration of energy balance) was associated with lower ad libitum EI at a subsequent buffet meal than following a 'low energy turnover' (non-exercise) condition. Despite differing nutrient balances during the conditions, $\mathrm{CHO}$ balance following the buffet meal was identical, suggesting that feeding was driven by the need to restore $\mathrm{CHO}$ balance to a set level. This is consistent with the finding that EI following a day of dietary $\mathrm{CHO}$ deprivation was designed to restore $\mathrm{CHO}$ balance rather than energy balance. ${ }^{112}$ Where $\mathrm{CHO}$ balance has been measured over longer periods (1-3 days) following the manipulation of glycogen availability, a negative $\mathrm{CHO}$ balance (indicating greater $\mathrm{CHO}$ oxidation than intake) has been shown to be predictive of greater ad libitum EI over the subsequent days. ${ }^{111}$ 113-116 Furthermore, a negative carbohydrate balance has been shown to be predictive of weight gain over a 4-year follow-up period. ${ }^{117}$ Although inferences concerning glycogen availability based on short-term $\mathrm{CHO}$ balances should be made cautiously, the partitioning of dietary $\mathrm{CHO}$ for storage rather than oxidation appears to be associated with lower EI and more stable body weight.

\section{DOES EXERCISE ALTER FOOD AND TASTE PREFERENCES?}

A contributor to the compensatory response to exercise could be alterations in food and taste preference. ${ }^{118}$ In a recent review, Elder and Roberts ${ }^{119}$ identified 12 studies investigating the acute effect of exercise on food palatability and taste perception. ${ }^{9}$ ${ }^{120-130}$ We have since identified further six studies that contribute to this literature. ${ }^{131-136}$ In terms of taste perception and preference, the outcomes are rather variable and show increases, no change and decreases in acuity of taste perception and rated preference for tastes after exercise. This between-study 
variation may be explained by differences in the exercise protocols adopted. The studies using longer and higher intensity exercise sessions (120-180 $\mathrm{min}$ ) tended to record the effects of exercise, ${ }^{124} 130$ whereas shorter, lower intensity exercise (10-30 min) studies did not report significant changes. ${ }^{123} 125$ Effects were more likely to be reported for perception and preference of salt taste than sweet or bitter taste. This suggests any effect of exercise on taste perception and preference is likely to be small or subject to a threshold of physical exertion or EE. Currently, no study has independently examined the roles of exertion and expenditure on taste perception and taste preference after exercise. Other studies have tested the effect of exercise on the palatability of whole meals or food items more generally. ${ }^{122} 126$ King et a $1^{122}$ found increased palatability ratings after high-fat and low-fat test meals, whereas Lluch et al ${ }^{126}$ found increased ratings for low-fat foods only. Finlayson et a ${ }^{137}$ measured hedonic response to images of food immediately before and after acute exercise at baseline and following 12 weeks of daily moderate intensity exercise. They reported an overall decrease in palatability ratings over the 12 weeks, however acute increases in food preference after the exercise session was associated with poorer weight loss response to the intervention. Finlayson et a ${ }^{132}$ measured reaction times - an implicit measure of wanting for food - in response to foods varying in fat content and sweet taste after 50 min of moderate intensity cycling (compared with no exercise) followed by a test meal. The authors observed increased reaction times (increased food wanting) after exercise among those participants who increased their EI compared with those whose EI did not change. The findings that individual differences in the hedonic evaluation of food after exercise are linked with food intake and poor weight loss outcome suggest that altered food preferences are a stable characteristic that may partially explain compensatory responses to exercise.

Exercise-induced changes in food preference imply a change in the hedonic or motivational response to food. These processes can be understood as separable psychological components of liking and wanting that can be dissociated in the brain ${ }^{138}$ and behaviourally in response to acute exercise. ${ }^{132}$ It has been hypothesised that exercise may act as a buffer for reward driven eating. ${ }^{139}$ In rats, chronic exercise has been shown to decrease the reinforcing value of self-administered cocaine. ${ }^{140}$ However, it is also possible that exercise at the acute level has an enhancing effect on reward (similar to a low dose of an addictive drug) via a sensitizing action. ${ }^{141}$ The deliberate choice of foods with high hedonic value (eg, fatty or sweet tasting 'treats') to reward virtuous behaviour or to regulate changes in psychological states could be associated with exercise-induced changes in mood (eg, ref 135) or stress. ${ }^{136}$ The effects of exercise on food preference can be linked with equal importance to the metabolic and cognitive consequences of engaging in physical activity. For example, the effect of exercise on food preference can depend on the eating behaviour traits, such as Restraint and Disinhibition, of the population studied. ${ }^{122} 126142143$

Exercise-induced changes in food reward could be an important consideration in the efficacy of exercise as a means to reduce overweight. In particular, an enhanced motivational drive or wanting for food after exercise may help to explain why some people overcompensate during acute eating episodes. ${ }^{132}$ Some individuals could be resistant to the beneficial effects of exercise due to a predisposition to compensate for exercise-induced EE as a result of physiologically or psychologically modulated changes in food preference.

\section{PSYCHOLOGICAL PROCESSES AND BEHAVIOURAL TRAITS}

There is evidence to suggest that eating behaviour traits measured using the Three Factor Eating Questionnaire (TFEQ) ${ }^{144}$ exert an influence on food intake and that they also play a role in weight loss interventions. ${ }^{143}$ The factors of Disinhibition and Restraint, in particular, have emerged as important eating behaviour traits that influence weight gain, weight loss and weight maintenance, and therefore can be deemed as psychological markers of appetite regulation. On the one hand, there are data to suggest that individuals with a high level of Disinhibition are more susceptible to overcompensate for the energy expended during exercise, ${ }^{145}$ whereas exercise can also exert a positive influence over appetite control in individuals who show susceptibility towards opportunistic eating. For example, in lean women, an acute bout of exercise has been found to reduce motivation to eat and increase preference for low-fat foods. ${ }^{146}$ Conversely, in lean women with a high level of Restraint, an acute bout of exercise increased the perceived pleasantness of low-fat food and reduced the motivation to eat. ${ }^{126}$ In concordance with this, lean and overweight males with high Restraint did not show a counter-regulatory eating response (an overeating response initiated by the breakdown of cognitive Restraint) following a bout of moderate intensity exercise. ${ }^{147}$ Therefore, the influence of an acute bout of exercise appears to be beneficial, at least in the short term, for men and women who exhibit a high Restraint score.

In longer-term interventions, there is a consistent and robust finding that successful weight loss is associated with a decrease in Disinhibition and Hunger, and an increase in Restraint (eg, refs 148-152). Independent of the type of energy balance perturbation, individuals who are successful in losing weight respond by increasing their control over eating (ie, Restraint) and reducing their opportunistic eating behaviour. More specifically, Butryn et a ${ }^{153}$ found that individuals who showed a larger reduction in their level of Internal Disinhibition (eg, eating in response to negative affect) experienced the greatest weight loss. ${ }^{153}$ Two studies have examined the influence of exercise over a longer term on psychological aspects of appetite regulation.

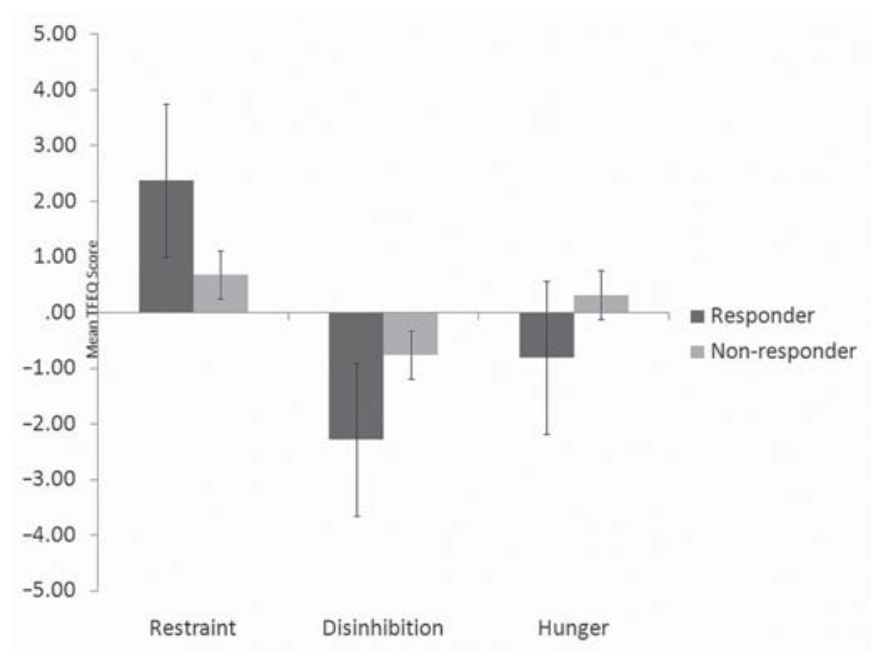

Figure 4 Mean ( \pm SEM) changes in the Three Factor Eating Questionnaire (TFEO) scores of Restraint, Disinhibition and Hunger after 12 weeks of supervised exercise. Data are displayed for responders and non-responders who lost more than and less than the expected weight, respectively. 


\section{What is already known on this topic}

Although there are several reviews of the effects of exercise on appetite, there is no information on the proposed mechanisms on the relationship. However, there is information on the summary of how exercise affects appetite, but nothing on the various behavioural, physiological and psychological processes involved.

\section{What this study adds}

This review adds value by providing a collective discussion of how the behavioural, physiological and psychological processes might influence compensatory responses to exercise and partially explains the individual variability.

Keim et al ${ }^{154}$ found that following a 4 -month exercise intervention (aerobic exercise or resistance training 5 days/week), reduced-obese women could be separated into over- and under-compensators. Those who overate were characterised by high Disinhibition and Hunger scores on the TFEQ, whereas the under-eaters showed a decrease in Disinhibition and Hunger scores and an increase in Restraint score during the intervention. In line with this, a recent 3 -month exercise intervention, designed to expend $500 \mathrm{kcal} / \mathrm{day}$, with no dietary intervention, ${ }^{22} 24$ demonstrated that overweight and obese individuals with a higher baseline Disinhibition experienced a greater weight loss. In addition, those individuals who experienced a decrease in their level of Disinhibition and an increase in Restraint had a higher weight loss. ${ }^{155}$ Figure 4 shows data originating from King et $a^{24}$ demonstrating how changes in TFEQ eating behaviour traits are affected differentially, depending on the actual weight loss experienced. That is, those who lost less weight than expected (non-responders) experienced lower decreases in Disinhibition and increases in Restraint than those who lost equal to, or more than the expected weight (responders). Of course, it is not clear whether it is exercise per se, or weight loss that is driving these changes, but it is clear that exercise can be used to modify eating behaviour traits, which are associated with susceptibility to weight gain. By identifying and characterising psychological markers of eating behaviour, the efficacy of exercise on weight loss could be improved.

\section{SUMMARY}

This review has identified the current state of play regarding the interaction between exercise and appetite, with a focus on individual variability and compensatory responses. It is clear that although the phenomenon of exercise-induced interindividual variability in responses was highlighted over 20 years ago, it has not been exploited, and the characterisation of this variability can be used to identify resistance to exercise-induced weight loss and to more efficient weight management strategies. Resistance to exercise-induced weight loss is partially explained by orexigenic responses in eating behaviour, which are mediated by physiological and psychological processes. A better understanding of how these underlying processes collectively contribute to a lower-than-expected weight loss will determine why exercise is not the most effective weight loss method for some individuals.

\section{Competing interests None.}

Provenance and peer review Not commissioned; externally peer reviewed

\section{REFERENCES}

1. King NA, Caudwell $P$, Hopkins $M$, et al. Metabolic and behavioral compensatory responses to exercise interventions: barriers to weight loss. Obesity (Silver Spring) 2007;15:1373-83.

2. King NA, Burley VJ, Blundell JE. Exercise-induced suppression of appetite: effects on food intake and implications for energy balance. Eur J Clin Nutr 1994;48:715-24

3. King NA, Blundell JE. High-fat foods overcome the energy expenditure induced by high-intensity cycling or running. Eur J Clin Nutr 1995;49:114-23.

4. Essig DA, Alderson NL, Ferguson MA, et al. Delayed effects of exercise on the plasma leptin concentration. Metab Clin Exp 2000;49:395-9.

5. George VA, Morganstein A. Effect of moderate intensity exercise on acute energy intake in normal and overweight females. Appetite 2003;40:43-6.

6. Tsofliou F, Pitsiladis YP, Malkova D, et al. Moderate physical activity permits acute coupling between serum leptin and appetite-satiety measures in obese women. Int J Obes Relat Metab Disord 2003;27:1332-9.

7. King NA, Lluch A, Stubbs RJ, et al. High dose exercise does not increase hunger or energy intake in free living males. Eur J Clin Nutr 1997;51:478-83.

8. Edholm 0G, Fletcher JG, Widdowson EM, et al. The energy expenditure and food intake of individual men. Br J Nutr 1955;9:286-300.

9. Saris W, Eck P, Schroder U, et al. Taste perception during endurance exercise. Med Sci Sports Exerc 1991;24:s71.

10. Pomerleau M, Imbeault P, Parker T, et al. Effects of exercise intensity on food intake and appetite in women. Am J Clin Nutr 2004;80:1230-6.

11. Stubbs RJ, Hughes DA, Johnstone AM, et al. Rate and extent of compensatory changes in energy intake and expenditure in response to altered exercise and diet composition in humans. Am J Physiol Regul Integr Comp Physiol 2004;286:R350-8.

12. Whybrow $\mathbf{S}$, Hughes DA, Ritz $\mathrm{P}$, et al. The effect of an incremental increase in exercise on appetite, eating behaviour and energy balance in lean men and women feeding ad libitum. Br J Nutr 2008;100:1109-15.

13. Long SJ, Hart K, Morgan LM. The ability of habitual exercise to influence appetite and food intake in response to high- and low-energy preloads in man. Br J Nutr 2002;87:517-23.

14. Van Walleghen EL, Orr JS, Gentile CL, et al. Habitual physical activity differentially affects acute and short-term energy intake regulation in young and older adults. Int J Obes (Lond) 2007;31:1277-85.

15. Pritchard JE, Nowson CA, Wark JD. A worksite program for overweight middleaged men achieves lesser weight loss with exercise than with dietary change. J Am Diet Assoc 1997; 97:37-42.

16. Donnelly JE, Jacobsen DJ, Heelan KS, et al. The effects of 18 months of intermittent vs. continuous exercise on aerobic capacity, body weight and composition, and metabolic fitness in previously sedentary, moderately obese females. Int J Obes Relat Metab Disord 2000;24:566-72.

17. Cox KL, Burke V, Morton AR, et al. The independent and combined effects of 16 weeks of vigorous exercise and energy restriction on body mass and composition in free-living overweight men-a randomized controlled trial. Metab Clin Exp 2003;52:107-15.

18. Donnelly JE, Hill JO, Jacobsen DJ, et al. Effects of a 16-month randomized controlled exercise trial on body weight and composition in young, overweight men and women: the Midwest Exercise Trial. Arch Intern Med 2003;163:1343-50.

19. Woo R, Pi-Sunyer FX. Effect of increased physical activity on voluntary intake in lean women. Metab Clin Exp 1985;34:836-41.

20. Lim CL, Lee LK. The effects of 20 weeks basic military training program on body composition, V02max and aerobic fitness of obese recruits. $J$ Sports Med Phys Fitness 1994;34:271-8.

21. Desgorces FD, Chennaoui M, Drogou C, et al. Relationships between leptin levels and carbohydrate intake during rowing training. J Sports Med Phys Fitness 2008;48:83-9.

22. King NA, Hopkins M, Caudwell $P$, et al. Individual variability following 12 weeks of supervised exercise: identification and characterization of compensation for exercise-induced weight loss. Int J Obes (Lond) 2008;32:177-84.

23. Caudwell $\mathbf{P}$, Hopkins $M$, King NA, et al. Exercise alone is not enough: weight loss also needs a healthy (Mediterranean) diet? Public Health Nutr 2009;12:1663-6.

24. King NA, Caudwell PP, Hopkins M, et al. Dual-process action of exercise on appetite control: increase in orexigenic drive but improvement in meal-induced satiety. Am J Clin Nutr 2009;90:921-7.

25. Stunkard A. The management of obesity. N Y State J Med 1958;58:79-87. 
26. Davidson MH, Hauptman J, DiGirolamo M, et al. Weight control and risk factor reduction in obese subjects treated for 2 years with orlistat: a randomized controlled trial. JAMA 1999;281:235-42.

27. James WP, Astrup A, Finer N, et al. Effect of sibutramine on weight maintenance after weight loss: a randomised trial. STORM Study Group. Sibutramine Trial of Obesity Reduction and Maintenance. Lancet 2000;356:2119-25.

28. Wadden TA, Berkowitz RI, Womble LG, et al. Randomized trial of lifestyle modification and pharmacotherapy for obesity. N Engl J Med 2005;353:2111-20.

29. Poehlman ET, Tremblay A, Després JP, et al. Genotype-controlled changes in body composition and fat morphology following overfeeding in twins. Am J Clin Nutr 1986; 43:723-31.

30. Bouchard C, Tremblay A, Després JP, et al. The response to exercise with constant energy intake in identical twins. Obes Res 1994;2:400-10.

31. Borg P, Kukkonen-Harjula K, Fogelholm M, et al. Effects of walking or resistance training on weight loss maintenance in obese, middle-aged men: a randomized trial. Int J Obes Relat Metab Disord 2002;26:676-83.

32. Donnelly JE, Smith BK. Is exercise effective for weight loss with ad libitum diet? Energy balance, compensation, and gender differences. Exerc Sport Sci Rev 2005;33:169-74.

33. Colley RC, Hills AP, O'Moore-Sullivan TM, et al. Variability in adherence to an unsupervised exercise prescription in obese women. Int J Obes (Lond) 2008; 32:837-44

34. Barwell ND, Malkova D, Leggate M, et al. Individual responsiveness to exerciseinduced fat loss is associated with change in resting substrate utilization. Metab Clin Exp 2009:58:1320-8.

35. Boutcher SH, Dunn SL. Factors that may impede the weight loss response to exercise-based interventions. Obes Rev 2009;10:671-80.

36. Fogelholm M. Physical activity, fitness and fatness: relations to mortality, morbidity and disease risk factors. A systematic review. Obes Rev 2010;11:202-21.

37. Gray R. Health warning - exercise makes you fat. Daily Telegraph 24 August 2009. http://www.telegraph.co.uk/science/6083234/Health-warning-exercisemakes-you-fat.html (accessed 6 May 2011)

38. Cloud J. Why exercise won't make you thin. Time Magazine 9 August 2009. http://www.time.com/time/health/article/0,8599,1914857,00.html (accessed 6 May 2011).

39. King NA, Hopkins M, Caudwell P, et al. Beneficial effects of exercise: shifting the focus from body weight to other markers of health. Br J Sports Med 2009:43:924-7.

40. Blundell JE, Levin F, King NA, et al. Overconsumption and obesity: peptides and susceptibility to weight gain. Regul Pept 2008;149:32-8.

41. Sørensen TI. Conference on "Multidisciplinary approaches to nutritional problems". Symposium on "Diabetes and health". Challenges in the study of causation of obesity. Proc Nutr Soc 2009;68:43-54.

42. Geliebter A. Gastric distension and gastric capacity in relation to food intake in humans. Physiol Behav 1988;44:665-8.

43. Read N, French $\mathrm{S}$, Cunningham $\mathrm{K}$. The role of the gut in regulating food intake in man. Nutr Rev 1994;52:1-10.

44. Jackson SJ, Leahy FE, Jebb SA, et al. Frequent feeding delays the gastric emptying of a subsequent meal. Appetite 2007:48:199-205.

45. Hunt J. A possible relation between the regulation of gastric emptying and food intake. Am J Physiol Gastrointest Liver Physiol 1980;239:1.

46. Sepple CP, Read NW. Gastrointestinal correlates of the development of hunger in man. Appetite 1989;13:183-91.

47. Bergmann JF, Chassany 0, Petit A, et al. Correlation between echographic gastric emptying and appetite: influence of psyllium. Gut 1992;33:1042-3.

48. Jackson SJ, Leahy FE, McGowan AA, et al. Delayed gastric emptying in the obese: an assessment using the non-invasive (13)C-octanoic acid breath test. Diabetes Obes Metab 2004;6:264-70.

49. Campbell J, Mitchell M, Powell A. The influence of exercise on digestion. Guy's Hosp Rep 1928;78:279-93.

50. Hellenbrandt $\mathbf{F}$, Tepper R. Studies on the influence of exercise on the digestive work of the stomach. Its effect on emptying time. Am J Physiol 1934;107:355-63.

51. Fordtran JS, Saltin B. Gastric emptying and intestinal absorption during prolonged severe exercise. J Appl Physiol 1967;23:331-5.

52. Costill DL, Saltin B. Factors limiting gastric emptying during rest and exercise. J Appl Physiol 1974;37:679-83.

53. Ramsbottom N, Hunt JN. Effect of exercise on gastric emptying and gastric secretion. Digestion 1974;10:1-8.

54. Neufer PD, Young AJ, Sawka MN. Gastric emptying during walking and running: effects of varied exercise intensity. Eur J Appl Physiol Occup Physiol 1989;58:440-5

55. Marzio L, Formica P, Fabiani F, et al. Influence of physical activity on gastric emptying of liquids in normal human subjects. Am J Gastroenterol 1991:86:1433-6

56. Leiper JB, Broad NP, Maughan RJ. Effect of intermittent high-intensity exercise on gastric emptying in man. Med Sci Sports Exerc 2001;33:1270-8.
57. Leiper JB, Nicholas CW, Ali A, et al. The effect of intermittent highintensity running on gastric emptying of fluids in man. Med Sci Sports Exerc 2005; 37:240-7.

58. Cammack J, Read NW, Cann PA, et al. Effect of prolonged exercise on the passage of a solid meal through the stomach and small intestine. Gut 1982;23:957-61

59. Neufer PD, Costill DL, Fink WJ, et al. Effects of exercise and carbohydrate composition on gastric emptying. Med Sci Sports Exerc 1986;18:658-62.

60. Keeling WF, Harris A, Martin BJ. Orocecal transit during mild exercise in women J Appl Physiol 1990;68:1350-3.

61. Feldman M, Nixon JV. Effect of exercise on postprandial gastric secretion and emptying in humans. J Appl Physiol 1982;53:851-4.

62. Brown BP, Ketelaar MA, Schulze-Delrieu K, et al. Strenuous exercise decreases motility and cross-sectional area of human gastric antrum. A study using ultrasound. Dig Dis Sci 1994;39:940-5.

63. Lu CL, Shidler N, Chen JD. Enhanced postprandial gastric myoelectrical activity after moderate-intensity exercise. Am J Gastroenterol 2000;95:425-31.

64. Kato M, Sakai T, Yabe K, et al. Gastric myoelectrical activity increases after moderate-intensity exercise with no meals under suppressed vagal nerve activity Jpn J Physiol 2004;54:221-8.

65. Houmard JA, Egan PC, Johns RA, et al. Gastric emptying during $1 \mathrm{~h}$ of cycling and running at 75\% V02max. Med Sci Sports Exerc 1991;23:320-5.

66. Meyer J. Motility of the stomach and gastroduodenal junction. In: Johnson LR, ed. Physiology of the Gastrointestinal Tract. Second edition. New York: Raven Press 1987:613-29.

67. Rehrer NJ, Meijer GA. Biomechanical vibration of the abdominal region during running and bicycling. J Sports Med Phys Fitness 1991;31:231-4.

68. Shimamoto C, Hirata I, Hiraike Y, et al. Evaluation of gastric motor activity in the elderly by electrogastrography and the (13)C-acetate breath test. Gerontology 2002;48:381-6.

69. Carrió I, Estorch M, Serra-Grima R, et al. Gastric emptying in marathon runners. Gut 1989:30:152-5.

70. Cunningham KM, Daly J, Horowitz M, et al. Gastrointestinal adaptation to diets of differing fat composition in human volunteers. Gut 1991:32:483-6.

71. Covasa M, Ritter R. Adaptation to high-fat diet reduces inhibition of gastric emptying by CCK and intestinal oleate. Am J Physiol Regul Integr Comp Physiol 2000;278:166.

72. Brown NJ, Rumsey RD, Read NW. Gastrointestinal adaptation to enhanced small intestinal lipid exposure. Gut 1994;35:1409-12.

73. Harris A, Lindeman AK, Martin BJ. Rapid orocecal transit in chronically active persons with high energy intake. J Appl Physiol 1991;70:1550-3.

74. Camilleri M. Peripheral mechanisms in the control of appetite and related experimental therapies in obesity. Regul Pept 2009:156:24-7.

75. Heath RB, Jones R, Frayn KN, et al. Vagal stimulation exaggerates the inhibitory ghrelin response to oral fat in humans. J Endocrinol 2004;180:273-81.

76. Kallio J, Pesonen U, Karvonen MK, et al. Enhanced exercise-induced GH secretion in subjects with Pro7 substitution in the prepro-NPY. J Clin Endocrinol Metab 2001;86:5348-52.

77. Dall R, Kanaley J, Hansen TK, et al. Plasma ghrelin levels during exercise in healthy subjects and in growth hormone-deficient patients. Eur J Endocrinol 2002; 147:65-70.

78. Kraemer RR, Durand RJ, Acevedo E0, et al. Rigorous running increases growth hormone and insulin-like growth factor-I without altering ghrelin Exp Biol Med (Maywood) 2004;229:240-6.

79. Schmidt A, Maier C, Schaller G, et al. Acute exercise has no effect on ghrelin plasma concentrations. Horm Metab Res 2004;36:174-7.

80. Burns SF, Broom DR, Miyashita M, et al. A single session of treadmill running has no effect on plasma total ghrelin concentrations. J Sports Sci 2007;25:635-42.

81. Jürimäe $\mathbf{J}$, Hofmann $P$, Jürimäe $T$, et al. Plasma ghrelin responses to acute sculling exercises in elite male rowers. Eur J Appl Physiol 2007;99:467-74.

82. Vestergaard ET, Dall R, Lange $\mathrm{KH}$, et al. The ghrelin response to exercise before and after growth hormone administration. J Clin Endocrinol Metab 2007:92:297-303.

83. Christ ER, Zehnder M, Boesch C, et al. The effect of increased lipid intake on hormonal responses during aerobic exercise in endurance-trained men. Eur J Endocrinol 2006;154:397-403.

84. Martins C, Morgan L, Truby H. A review of the effects of exercise on appetite regulation: an obesity perspective. Int J Obes (Lond) 2008;32:1337-47.

85. Broom DR, Stensel DJ, Bishop NC, et al. Exercise-induced suppression of acylated ghrelin in humans. J App/ Physiol 2007;102:2165-71.

86. Marzullo P, Salvadori A, Brunani A, et al. Acylated ghrelin decreases during acute exercise in the lean and obese state. Clin Endocrinol (Oxf) 2008;69:970-1.

87. Martins C, Morgan LM, Bloom SR, et al. Effects of exercise on gut peptides, energy intake and appetite. J Endocrinol 2007;193:251-8.

88. Ueda SY, Yoshikawa T, Katsura Y, et al. Changes in gut hormone levels and negative energy balance during aerobic exercise in obese young males. J Endocrinol 2009;201:151-9. 
89. Leidy HJ, Gardner JK, Frye BR, et al. Circulating ghrelin is sensitive to changes in body weight during a diet and exercise program in normal-weight young women. $J$ Clin Endocrinol Metab 2004:89:2659-64.

90. Foster-Schubert KE, McTiernan A, Frayo RS, et al. Human plasma ghrelin levels increase during a one-year exercise program. J Clin Endocrinol Metab 2005;90:820-5

91. Kelishadi R, Hashemipour M, Mohammadifard N, et al. Short- and long-term relationships of serum ghrelin with changes in body composition and the metabolic syndrome in prepubescent obese children following two different weight loss programmes. Clin Endocrinol (0xf) 2008;69:721-9.

92. Kim HJ, Lee S, Kim TW, et al. Effects of exercise-induced weight loss on acylated and unacylated ghrelin in overweight children. Clin Endocrinol (Oxf) 2008;68:416-22.

93. Ravussin E, Tschöp M, Morales S, et al. Plasma ghrelin concentration and energy balance: overfeeding and negative energy balance studies in twins. $J$ Clin Endocrinol Metab 2001:86:4547-51.

94. Jones TE, Basilio JL, Brophy PM, et al. Long-term exercise training in overweight adolescents improves plasma peptide YY and resistin. Obesity (Silver Spring) 2009;17:1189-95

95. Mackelvie KJ, Meneilly GS, Elahi D, et al. Regulation of appetite in lean and obese adolescents after exercise: role of acylated and desacyl ghrelin. $J$ Clin Endocrinol Metab 2007:92:648-54.

96. Martins C, Kulseng B, King NA, et al. The effects of exercise-induced weight loss on appetite-related peptides and motivation to eat. J Clin Endocrinol Metab 2010;95:1609-16.

97. Garcia JM, Iyer D, Poston WS, et al. Rise of plasma ghrelin with weight loss is not sustained during weight maintenance. Obesity (Silver Spring) 2006;14:1716-23.

98. Bailey DM, Davies B, Castell LM, et al. Physical exercise and normobaric hypoxia: independent modulators of peripheral cholecystokinin metabolism in man. J Appl Physiol 2001;90:105-13

99. Hurley RS, Bossetti BM, O'Dorisio TM, et al. The effect of exercise training on body weight and peptide hormone patterns in normal weight college-age men. J Sports Med Phys Fitness 1991;31:52-6.

100. Chanoine JP, Mackelvie KJ, Barr SI, et al. GLP-1 and appetite responses to a meal in lean and overweight adolescents following exercise. Obesity (Silver Spring) 2008;16:202-4.

101. Spannagel AW, Nakano I, Tawil T, et al. Adaptation to fat markedly increases pancreatic secretory response to intraduodenal fat in rats. Am J Physiol 1996;270:G128-35.

102. Lee HM, Wang G, Englander EW, et al. Ghrelin, a new gastrointestinal endocrine peptide that stimulates insulin secretion: enteric distribution, ontogeny, influence of endocrine, and dietary manipulations. Endocrinology 2002;143:185-90.

103. Woods SC, Seeley RJ, Rushing PA, et al. A controlled high-fat diet induces an obese syndrome in rats. J Nutr 2003;133:1081-7.

104. French SJ, Murray B, Rumsey RD, et al. Adaptation to high-fat diets: effects on eating behaviour and plasma cholecystokinin. Br J Nutr 1995;73:179-89.

105. Leonhardt M, Langhans W. Fatty acid oxidation and control of food intake. Physiol Behav 2004;83:645-51.

106. Friedman MI. Control of energy intake by energy metabolism. Am J Clin Nutr 1995;62:1096-100S

107. Flatt JP. Dietary fat, carbohydrate balance, and weight maintenance: effects of exercise. Am J Clin Nutr 1987:45:296-306.

108. Flatt JP. Glycogen levels and obesity. Int J Obes Relat Metab Disord 1996;20(Suppl 2):S1-11.

109. Alméras N, Lavallée N, Després JP, et al. Exercise and energy intake: effect of substrate oxidation. Physiol Behav 1995;57:995-1000

110. Imbeault P, Saint-Pierre S, Alméras N, et al. Acute effects of exercise on energy intake and feeding behaviour. Br J Nutr 1997;77:511-21.

111. Burton FL, Malkova D, Caslake MJ, et al. Substrate metabolism, appetite and feeding behaviour under low and high energy turnover conditions in overweight women. Br J Nutr 2010;104:1249-59.

112. Sparti A, Windhauser MM, Champagne CM, et al. Effect of an acute reduction in carbohydrate intake on subsequent food intake in healthy men. Am J Clin Nutr 1997:66:1144-50.

113. Stubbs RJ, Harbron CG, Murgatroyd PR, et al. Covert manipulation of dietary fat and energy density: effect on substrate flux and food intake in men eating ad libitum. Am J Clin Nutr 1995;62:316-29.

114. Snitker S, Larson DE, Tataranni PA, et al. Ad libitum food intake in humans after manipulation of glycogen stores. Am J Clin Nutr 1997;65:941-6.

115. Pannacciulli N, Salbe AD, Ortega E, et al. The 24-h carbohydrate oxidation rate in a human respiratory chamber predicts ad libitum food intake. Am J Clin Nutr 2007;86:625-32.

116. Galgani JE, de Jonge L, Most MM, et al. Effect of a 3-day high-fat feeding period on carbohydrate balance and ad libitum energy intake in humans. Int J Obes (Lond) 2010:34:886-91.

117. Eckel RH, Hernandez TL, Bell ML, et al. Carbohydrate balance predicts weight and fat gain in adults. Am J Clin Nutr 2006;83:803-8.
118. Bellisle F. Food choice, appetite and physical activity. Public Health Nutr 1999;2:357-61.

119. Elder SJ, Roberts SB. The effects of exercise on food intake and body fatness: a summary of published studies. Nutr Rev 2007;65:1-19.

120. Thompson DA, Wolfe LA, Eikelboom R. Acute effects of exercise intensity on appetite in young men. Med Sci Sports Exerc 1988;20:222-7.

121. Takamata A, Mack GW, Gillen CM, et al. Sodium appetite, thirst, and body fluid regulation in humans during rehydration without sodium replacement. Am J Physiol 1994;266:R1493-502.

122. King NA, Snell L, Smith RD, et al. Effects of short-term exercise on appetite responses in unrestrained females. Eur J Clin Nutr 1996;50:663-7.

123. Nakagawa M, Mizuma K, Inui T. Changes in taste perception following mental or physical stress. Chem Senses 1996;21:195-200.

124. Westerterp-Plantenga MS, Verwegen CR, ljedema MJ, et al. Acute effects of exercise or sauna on appetite in obese and nonobese men. Physiol Behav 1997:62:1345-54

125. Horio $\mathbf{T}$, Kawamura Y. Influence of physical exercise on human preferences for various taste solutions. Chem Senses 1998;23:417-21.

126. Lluch A, King NA, Blundell JE. Exercise in dietary restrained women: no effect on energy intake but change in hedonic ratings. Eur J Clin Nutr 1998;52:300-7.

127. King NA, Appleton K, Rogers PJ, et al. Effects of sweetness and energy in drinks on food intake following exercise. Physiol Behav 1999;66:375-9.

128. Leshem M, Abutbul A, Eilon R. Exercise increases the preference for salt in humans. Appetite 1999;32:251-60.

129. Horio T. Effect of physical exercise on human preference for solutions of various sweet substances. Percept Mot Skills 2004;99:1061-70.

130. Appleton KM. Changes in the perceived pleasantness of fluids before and after fluid loss through exercise: a demonstration of the association between perceived pleasantness and physiological usefulness in everyday life. Physiol Behav 2005:83:813-19.

131. Wald N, Leshem M. Salt conditions a flavor preference or aversion after exercise depending on $\mathrm{NaCl}$ dose and sweat loss. Appetite 2003:40:277-84.

132. Finlayson G, Bryant E, Blundell JE, et al. Acute compensatory eating following exercise is associated with implicit hedonic wanting for food. Physiol Behav 2009;97:62-7.

133. Havermans RC, Salvy SJ, Jansen A. Single-trial exercise-induced taste and odor aversion learning in humans. Appetite 2009;53:442-5.

134. Passe DH, Stofan JR, Rowe CL, et al. Exercise condition affects hedonic responses to sodium in a sport drink. Appetite 2009;52:561-7.

135. Schneider KL, Spring B, Pagoto SL. Exercise and energy intake in overweight, sedentary individuals. Eat Behav 2009:10:29-35.

136. Taylor AH, Oliver AJ. Acute effects of brisk walking on urges to eat chocolate, affect, and responses to a stressor and chocolate cue. An experimental study. Appetite 2009;52:155-60.

137. Finlayson G, King $\mathrm{N}$, Blundell J. The role of implicit wanting in relation to explicit liking and wanting for food: implications for appetite control. Appetite 2008;50:120-7.

138. Berridge KC, Robinson TE. Parsing reward. Trends Neurosci 2003;26:507-13.

139. Davis C, Woodside DB. Sensitivity to the rewarding effects of food and exercise in the eating disorders. Compr Psychiatry 2002;43:189-94.

140. Smith MA, Schmidt KT, Iordanou JC, et al. Aerobic exercise decreases the positive-reinforcing effects of cocaine. Drug Alcohol Depend 2008;98:129-35.

141. Lett BT, Grant VL, Gaborko LL. A small amount of wheel running facilitates eating in nondeprived rats. Behav Neurosci 1996;110:1492-5.

142. Lluch A, King NA, Blundell JE. No energy compensation at the meal following exercise in dietary restrained and unrestrained women. Br J Nutr 2000;84:219-25.

143. Bryant EJ, King NA, Blundell JE. Disinhibition: its effects on appetite and weight regulation. Obes Rev 2008;9:409-19.

144. Stunkard AJ, Messick S. The three-factor eating questionnaire to measure dietary restraint, disinhibition and hunger. J Psychosom Res 1985;29:71-83.

145. Visona C, George VA. Impact of dieting status and dietary restraint on postexercise energy intake in overweight women. Obes Res 2002;10:1251-8.

146. Bryant $\mathbf{E}$, Finlayson $\mathrm{G}$, King N, et al. The influence of acute exercise on liking and preference for food on high trait Disinhibition women. Obes Rev 2006; 7:343.

147. Harris CL, George VA. The impact of dietary restraint and moderate-intensity exercise on post-exercise energy intake in sedentary males. Eat Behav 2008:9:415-22.

148. Pekkarinen T, Takala I, Mustajoki P. Two year maintenance of weight loss after a VLCD and behavioural therapy for obesity: correlation to the scores of questionnaires measuring eating behaviour. Int J Obes Relat Metab Disord 1996;20:332-7.

149. Foster GD, Wadden TA, Swain RM, et al. The Eating Inventory in obese women: clinical correlates and relationship to weight loss. Int J Obes Relat Metab Disord 1998;22:778-85

150. Westerterp-Plantenga MS, Kempen KP, Saris WH. Determinants of weight maintenance in women after diet-induced weight reduction. Int J Obes Relat Metab Disord 1998:22:1-6.

151. Adam TC, Westerterp-Plantenga MS. Activity-induced GLP-1 release in lean and obese subjects. Physiol Behav 2004;83:459-66. 
152. Teixeira PJ, Silva MN, Coutinho SR, et al. Mediators of weight loss and weight loss maintenance in middle-aged women. Obesity (Silver Spring) 2010;18:725-35.

153. Butryn ML, Thomas JG, Lowe MR. Reductions in internal disinhibition during weight loss predict better weight loss maintenance. Obesity (Silver Spring) 2009;17:1101-3.
154. Keim NL, Canty DJ, Barbieri TF, et al. Effect of exercise and dietary restraint on energy intake of reduced-obese women. Appetite 1996;26:55-70.

155. Bryant E. High trait disinhibition associated with better success at exerciseinduced weight loss. Obes Facts 2009;2:211. 


\section{BJSM}

\section{Exercise, appetite and weight management: understanding the compensatory responses in eating behaviour and how they contribute to variability in exercise-induced weight loss}

N A King, K Horner, A P Hills, et al.

Br J Sports Med published online May 19, 2011

doi: $10.1136 /$ bjsm.2010.082495

Updated information and services can be found at:

http://bjsm.bmj.com/content/early/2011/05/18/bjsm.2010.082495.full.html

\section{These include:}

References This article cites 152 articles, 43 of which can be accessed free at: http://bjsm.bmj.com/content/early/2011/05/18/bjsm.2010.082495.full.html\#ref-list-1

$\mathbf{P}<\mathbf{P} \quad$ Published online May 19, 2011 in advance of the print journal.

Email alerting Receive free email alerts when new articles cite this article. Sign up in service the box at the top right corner of the online article.

\section{Collections

\author{
Health education (274 articles) \\ Obesity (nutrition) (72 articles) \\ Obesity (public health) (72 articles)
}

Topic Articles on similar topics can be found in the following collections

Advance online articles have been peer reviewed, accepted for publication, edited and typeset, but have not not yet appeared in the paper journal. Advance online articles are citable and establish publication priority; they are indexed by PubMed from initial publication. Citations to Advance online articles must include the digital object identifier (DOIs) and date of initial publication.

To request permissions go to:

http://group.bmj.com/group/rights-licensing/permissions

To order reprints go to:

http://journals.bmj.com/cgi/reprintform

To subscribe to BMJ go to:

http://group.bmj.com/subscribe/ 


\section{Notes}

Advance online articles have been peer reviewed, accepted for publication, edited and typeset, but have not not yet appeared in the paper journal. Advance online articles are citable and establish publication priority; they are indexed by PubMed from initial publication. Citations to Advance online articles must include the digital object identifier (DOIs) and date of initial publication.

To request permissions go to:

http://group.bmj.com/group/rights-licensing/permissions

To order reprints go to:

http://journals.bmj.com/cgi/reprintform

To subscribe to BMJ go to:

http://group.bmj.com/subscribe/ 